Section Editor

Mitchell S.V. Elkind, MD, MS

Martin Sawires, MD Rudolf Knapp, MD Klaus Berek, MD

Address correspondence and reprint requests to Dr. Martin Sawires, Department of Neurology, BKH-Kufstein, Endach 27, 6330 Kufstein, Austria msawires@web.de

\title{
Teaching NeuroImages: \\ Schwannoma of the cauda equina
}

Figure MRI of the lumbar spine
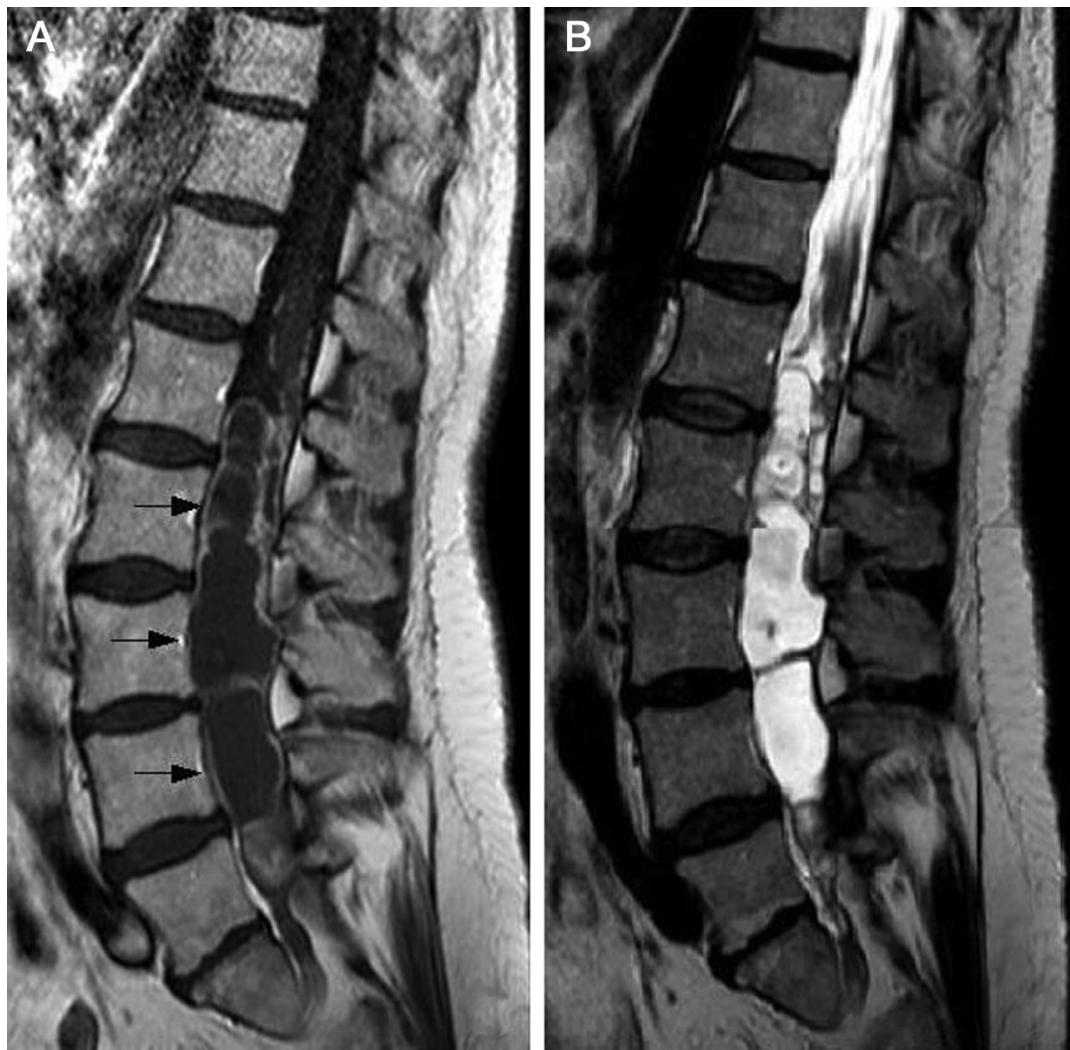

T1-weighted sequence after gadodiamide (A) and T2-weighted sequence (B). Cystic lesion ranging from L2 to the S1 level with contrast material uptake in the cystic wall (arrows).

A 50-year-old woman reported several years of progressive lower back pain in the supine position. Results of the neurologic examination were normal. MRI of the lumbar spine was performed (figure). After surgery, which revealed an intraspinal intradural schwannoma, the patient had no neurologic complaints. Schwannoma of the cauda equina usually develops at the L1-L2 level and causes back pain, sometimes limited to the supine position. ${ }^{1}$ MRI can distinguish this entity from disc herniation, which is sometimes a pitfall in the diagnosis. $^{2}$

\section{REFERENCES}

1. Wager M, Lapierre F, Blanc JL, Listrat A, Bataille B. Cauda equina tumors: a French multicenter retrospective review of 231 adult cases and review of the literature. Neurosurg Rev 2000;23:119-129.

2. Palma L, Mariottini A, Muzii VF, Bolognini A, Scarfo GB. Neurinoma of the cauda equina misdiagnosed as prolapsed lumbar disk: report of three cases. J Neurosurg Sci 1994;38:181-185. 


\title{
Neurology
}

\author{
Teaching NeuroImages: Schwannoma of the cauda equina \\ Martin Sawires, Rudolf Knapp and Klaus Berek \\ Neurology 2011;76;e105 \\ DOI 10.1212/WNL.0b013e31821ccc4c
}

This information is current as of May 23, 2011

\section{Updated Information \& Services}

\section{References}

\section{Subspecialty Collections}

Permissions \& Licensing

Reprints including high resolution figures, can be found at: http://n.neurology.org/content/76/21/e105.full

This article cites 2 articles, 0 of which you can access for free at: http://n.neurology.org/content/76/21/e105.full\#ref-list-1

This article, along with others on similar topics, appears in the following collection(s):

All Clinical Neurology

http://n.neurology.org/cgi/collection/all_clinical_neurology All Imaging

http://n.neurology.org/cgi/collection/all_imaging

All Oncology

http://n.neurology.org/cgi/collection/all_oncology

All Pain

http://n.neurology.org/cgi/collection/all_pain

Spinal cord tumor

http://n.neurology.org/cgi/collection/spinal_cord_tumor

Information about reproducing this article in parts (figures,tables) or in its entirety can be found online at:

http://www.neurology.org/about/about_the_journal\#permissions

Information about ordering reprints can be found online:

http://n.neurology.org/subscribers/advertise

Neurology ${ }^{\circledR}$ is the official journal of the American Academy of Neurology. Published continuously since 1951, it is now a weekly with 48 issues per year. Copyright Copyright $@ 2011$ by AAN Enterprises, Inc.. All rights reserved. Print ISSN: 0028-3878. Online ISSN: 1526-632X.

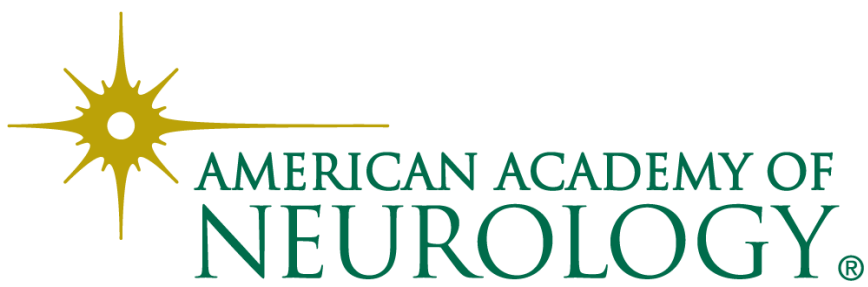

